\title{
Hospital admissions for lower respiratory tract infections among infants in the Canadian Arctic: a cohort study
}

\author{
Anna Banerji MD MPH, Val Panzov MD, Michael Young MD, Joan Robinson MD, Bonita Lee MD MSc, \\ Theo Moraes MD PhD, Muhammad Mamdani MPH PharmD, B. Louise Giles MD, Depeng Jiang PhD, \\ Danny Bisson BSc (Hons) MD, Marguerite Dennis RN, Johanne Morel MD, Judith Hall MSc, \\ Charles Hui MD, Bosco Paes MBBS, James B. Mahony PhD
}

See also www.cmajopen.ca/lookup/doi/10.9778/cmajo.20150052

Abstract

Background: It is unknown whether this burden of disease of lower respiratory tract infections is comparable across the Canadian Arctic. The objectives of this surveillance study were to compare the rates of hospital admission for lower respiratory tract infection and the severity of infection across Arctic Canada, and to describe the responsible viruses.

Methods: We performed a prospective multicentre surveillance study of infants less than 1 year of age admitted in 2009 with lower respiratory tract infection to all hospitals (5 regional, 4 tertiary) in the Northwest Territories, Nunavut and Nunavik to assess for regional differences. Nasopharyngeal aspirates were processed by means of a polymerase chain reaction respiratory viral panel, testing for 20 respiratory viruses and influenza $A(\mathrm{H} 1 \mathrm{~N} 1)$. The role of coinfection was assessed by means of regression analysis for length of stay (short: $<7 \mathrm{~d}$; long: > $14 \mathrm{~d}$ ). Outcomes compared included rates of lower respiratory tract infection, respiratory syncytial virus infection, transfer to tertiary hospital and severe lower respiratory tract infection (respiratory failure, intubation and mechanical ventilation, and/or cardiopulmonary resuscitation).

Results: There were 348 admissions for lower respiratory tract infection in the population of interest in 2009. Rates of admission per 1000 live births varied significantly, from 39 in the Northwest Territories to 456 in Nunavik $(p<0.001)$. The rates of tertiary admissions and severe lower respiratory tract infection per 1000 live births in the Northwest Territories were 5.6 and 1.4, respectively, compared to 55.9 and 17.1, respectively, in Nunavut and 52.0 and 20.0, respectively, in Nunavik $(p \leq 0.001)$. Respiratory syncytial virus was the most common virus identified (124 cases [ $41.6 \%$ of those tested]), and coinfection was detected in 51 cases (41.1\%) of infection with this virus. Longer length of stay was associated with coinfection (odds ratio [OR] 2.64) and underlying risk factors (OR 4.39). Length of stay decreased by $32.2 \%$ for every 30 -day increase in age (OR 0.68).

Interpretation: Nunavut and Nunavik have very elevated rates of lower respiratory tract infection, with severe outcomes. Respiratory syncytial virus was the most common virus identified, and coinfection was associated with longer length of stay. Targeted public health interventions are required to reduce the burden of disease for infants residing in these Arctic regions.

\section{$\mathrm{L}$} ower respiratory tract infections are a leading cause of hospital admissions among infants less than 1 year of age globally. ${ }^{1}$ Circumpolar regions have significantly elevated admission rates compared to more southern regions..$^{2-6}$ Rates of admission for lower respiratory tract infections in the first year of life of 315 per 1000 infant-years in the Qikiqtaaluk Region (Baffin), Nunavut ${ }^{7}$ and 590 per 1000 live births in the Kitikmeot Region, Nunavut ${ }^{8}$ have been reported, in contrast to typical rates of 5-20 per 1000 infants in the United States. ${ }^{910} \mathrm{It}$ is unknown whether this burden of disease is comparable across the Canadian Arctic. As rates vary from year to year, comparison of regional rates requires data collection over the same period. This information has implications for public health policy and resource use.

Competing interests: See the end of the article.

This article has been peer reviewed.

Correspondence to: Anna Banerji, anna.banerji@utoronto.ca CMAJ Open 2016. DOI:10.9778/cmajo.20150051 
The risk factors contributing to elevated rates of hospital admission for lower respiratory tract infections in this population are likely multifactorial, and the role of specific infections is not clear. A previous surveillance study in the Qikiqtaaluk Region identified a substantial number of cases with multiple infections (coinfection). ${ }^{6,11}$ In 2009, influenza A (H1N1) virus emerged and disproportionately affected indigenous populations. ${ }^{12,13}$

The primary objective of this surveillance study was to compare hospital admission rates for lower respiratory tract infections, including respiratory syncytial virus infections, across the Canadian Arctic to assess for regional differences, specifically, to identify the regions with the highest burden of disease in 2009. Secondary objectives included describing the viruses identified and coinfections.

\section{Methods}

\section{Design}

This was a multicentre hospital-based surveillance study of infants admitted with a lower respiratory tract infection to all hospitals in the catchment area of the Northwest Territories and Nunavut, with the 3 Nunavut subregions of Kitikmeot, Kivalliq and Qikiqtaaluk, and with Nunavik (northern Que- bec) (Figure 1). The unit of analysis was the number of admissions. We included all infants less than 1 year of age residing in these regions who had been admitted with physiciandiagnosed lower respiratory tract infection between Jan. 1 and Dec. 31, 2009. Lower respiratory tract infection included bronchiolitis, pneumonia (simple or complex) and croup. In a prior study in the Qikiqtaaluk Region, there was complete correlation with the admission diagnosis for lower respiratory tract infection based on validation criteria of signs and symptoms for lower respiratory tract infection. ${ }^{11}$

\section{Setting}

The study included 5 regional hospitals in Yellowknife, Churchill, Iqaluit, Puvirnituq and Kuujjuaq, and 4 tertiary hospitals in Edmonton, Winnipeg, Ottawa and Montreal (Figure 1). Most communities in Arctic Canada have a health centre; however, infants who require hospital admission are admitted to regional or tertiary hospitals. Hospital transfers were considered a single admission. Referral patterns are similar across the Canadian Arctic. Each hospital had a site investigator and a trained research nurse on site to prospectively identify infants who met the inclusion criterion, obtain written informed consent, administer the questionnaire to the parent or guardian and collect specimens in all regions except

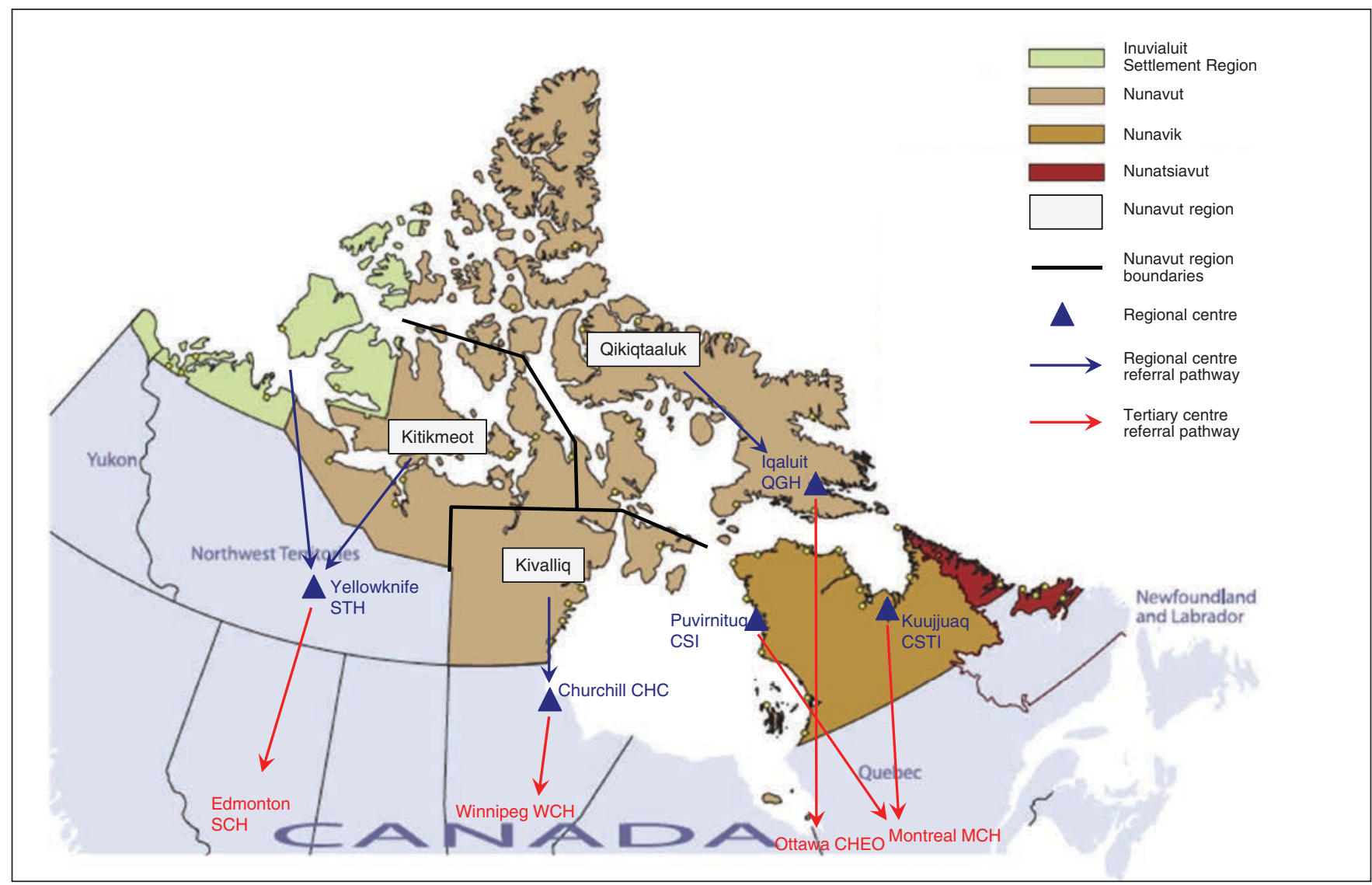

Figure 1: Map of Inuit regions in Canada, showing typical referral pathways in 2009. CHC = Churchill Health Centre, CHEO = Children's Hospital of Eastern Ontario, CSI = Centre de santé Inuulitsivik, CSTI = Centre de santé Tulattavik, MCH = Montréal Children's Hospital, QGH = Qikiqtani General Hospital, SCH = Stollery Children's Hospital, STH = Stanton Territorial Hospital, WCH = Winnipeg Children's Hospital. Adapted from Inuit Tapiriit Kanatami, https://www.itk.ca. 
the Qikiqtaaluk Region, where administrative delays resulted in retrospective data collection. (In the Qikiqtaaluk Region, children are admitted to the Qikiqtani General Hospital, whereas in the other regions of Nunavut, they are admitted outside of the territory.)

\section{Questionnaire and data collection}

The questionnaire documented the use of palivizumab ${ }^{14}$ and underlying risk factors for lower respiratory tract infection including preterm birth (less than 36 weeks' gestational age), chronic lung disease, substantial congenital heart disease, immunodeficiency, and congenital or neurologic conditions typically considered risk factors for severe respiratory syncytial virus infection. ${ }^{15}$ Outcomes included length of stay (short: < 7 d; long: > 14 d), transfer to a tertiary hospital and severe lower respiratory tract infection (defined as requiring mechanical ventilation [for respiratory failure] or cardiopulmonary resuscitation, or death). At the end of the study, a chart audit was conducted by the research nurse, site investigator or principal investigator at all participating sites for all admitted infants who were less than 1 year of age residing in the Arctic to identify missing patients and collect missing data retrospectively, and to validate the diagnosis of lower respiratory tract infection though discharge diagnosis.

\section{Laboratory testing}

Nasopharyngeal aspirates were processed at the Regional Virology Laboratory, McMaster University, Hamilton, Ontario by means of a viral multiplex polymerase chain reaction method on the xTAG Respiratory Viral Panel (Luminex Molecular Diagnostics), which included respiratory syncytial virus and 19 other viruses (influenza $A$ and $B$, parainfluenza types $1-4$, respiratory syncytial virus $A$ and $B$, adenovirus, rhinovirus/enterovirus, human metapneumovirus, severe acute respiratory syndrome virus-coronavirus and other emerging coronaviruses [OC43, 229E, NL63 and HKU1]). ${ }^{16,17}$ Piconaviruses (rhinovirus and enterovirus) are indistinguishable by polymerase chain reaction. Viral testing for clinical purposes was performed at the Provincial Public Health Laboratory, Edmonton, Cadham Provincial Laboratories, Winnipeg, and Montreal Children's Hospital. When influenza A (H1N1) emerged, in April 2009, a real-time polymerase chain reaction assay for influenza A virus was implemented for all specimens. ${ }^{18}$ Bacterial or fungal testing was ordered by the attending physician as clinically indicated. All positive results were recorded.

\section{Viral analysis}

We tabulated all infectious agents identified at admission, with their frequency as either isolated alone or in combination with another agent. For this analysis, each organism identified was considered 1 infection. We assessed viruses as a dichotomous variable ( $1 \mathrm{v} .>1)$ and by the number of viruses.

\section{Statistical analysis}

We compared demographic features between the Northwest Territories, Kitikmeot Region, Kivalliq Region, Qikiqtaaluk
Region and Nunavik. We obtained the number of births from Statistics Canada's vital statistics registry for births ${ }^{19}$ (Northwest Territories and Nunavut) or the regional government (Nunavik). We used the $\chi^{2}$ test or Fisher exact test to examine overall regional differences in prevalence rates of underlying conditions. We used a nonparametric test to examine the difference in median admission age across regions. We conducted logistic regression models to compare the demographic features for the Northwest Territories against those of each of the other 4 regions.

We calculated the annual incidence rate per 1000 live births of hospital admission for lower respiratory tract infection and for respiratory syncytial virus infection in 2009 among infants less than 1 year for the respective region. The denominator was the number of births in each region in 2009. On preliminary analysis, the rates for the Northwest Territories were noted to be significantly lower than those for the other regions $(p<0.001)$, and we compared them with those of each of the other 4 regions using logistic regression. Subsequently, we calculated the total rates of admission including the Northwest Territories and excluding the Northwest Territories. Rates of transfer to tertiary centres and severe lower respiratory tract infection were calculated per 1000 live births in each region and were compared across regions.

We used multivariate multinomial logistic regression models to estimate the odds ratio (OR) and 95\% confidence interval (CI) for the association between the number of viruses and long versus short length of stay, adjusted for age at admission (considered as units of $30 \mathrm{~d}$ for ease of interpretation) and underlying risk factors. We performed the statistical analyses using SAS version 9.3. All $p$ values were 2 -sided, and significance was set at a value of less than 0.05 .

\section{Ethics approval}

We obtained ethics and internal approval from all participating hospitals. The Applied Health Research Centre, St. Michael's Hospital, Toronto, coordinated the study. The study was licensed though the Aurora Research Institute and the Nunavut Research Institute. In addition, before commencing the study, we engaged in extensive consultation with Inuit advocacy groups.

\section{Results}

During 2009 there were 348 admissions for lower respiratory tract infection among 293 infants: 260 to regional centres alone, 66 to tertiary centres alone and 22 to both. Table 1 lists the demographic characteristics of the patients. The median age at admission was 114.5 (range 11-357) days. In 175 cases $(50.3 \%)$ the patient was a boy, and in 70 cases $(20.1 \%)$ the patient had underlying risk factors: in 65 cases $(18.7 \%)$ the infant was premature, and in $14(4.0 \%)$ the infant had chronic lung disease or congenital heart disease. The demographic characteristics were similar in all regions except the Northwest Territories, which had a significantly higher proportion of boys $(p=0.02)$. Only 1 infant admitted with respiratory syncytial virus infection had received prophylaxis with palivizumab. 


\section{OPEN}

Research

Table 2 compares the rates of lower respiratory tract infection and respiratory syncytial virus, tertiary admissions and severe lower respiratory tract infection across regions. The rate in the Northwest Territories was lower than in each of the other 4 regions $(p<0.001)$ for all variables. The rate of lower respiratory tract infection per 1000 live births was 39 in

Table 1: Demographic characteristics of cases of lower respiratory tract infection in infants who resided in the Canadian Arctic and were admitted to hospital in 2009 , by region

\begin{tabular}{|c|c|c|c|c|c|c|c|c|c|c|}
\hline \multirow[b]{3}{*}{ Characteristic } & \multicolumn{8}{|c|}{ Region; subregion } & \multirow{3}{*}{$\begin{array}{l}p \text { value for } \\
\text { comparison } \\
\text { between all } \\
\text { regions }\end{array}$} & \multirow{3}{*}{$\begin{array}{l}p \text { value } \\
\text { for NWT v. } \\
\text { KTR, } \\
\text { KQR, QIR, } \\
\text { NK* }\end{array}$} \\
\hline & \multirow[b]{2}{*}{ NWT } & \multicolumn{4}{|c|}{$\mathrm{NU}$} & \multirow[b]{2}{*}{ NK } & \multirow[b]{2}{*}{ All regions } & \multirow{2}{*}{$\begin{array}{l}\text { All regions } \\
\text { excluding } \\
\text { NWT }\end{array}$} & & \\
\hline & & Overall & KTR & KQR & QIR & & & & & \\
\hline No. of births in 2009 & 711 & 877 & 123 & 263 & 491 & 250 & 1838 & 1127 & - & - \\
\hline $\begin{array}{l}\text { No. of admissions for } \\
\text { LRTI }\end{array}$ & 28 & 206 & 41 & 73 & 92 & 114 & 348 & 320 & & \\
\hline $\begin{array}{l}\text { Male sex, no. (\%) of } \\
\text { admissions }\end{array}$ & $20(71.4)$ & $92(44.7)$ & $14(34.1)$ & $38(52.0)$ & $40(43.5)$ & $63(55.3)$ & $175(50.3)$ & $155(48.4)$ & 0.02 & 0.02 \\
\hline $\begin{array}{l}\text { Age at admission, } \\
\text { median (interquartile } \\
\text { range), d }\end{array}$ & $\begin{array}{c}147 \\
(84-168)\end{array}$ & $\begin{array}{c}109.5 \\
(53-202)\end{array}$ & $\begin{array}{c}168 \\
(65-197)\end{array}$ & $\begin{array}{c}82 \\
(44-168)\end{array}$ & $\begin{array}{c}90.5 \\
(44-223)\end{array}$ & $\begin{array}{c}136 \\
(69-222)\end{array}$ & $\begin{array}{c}114.5 \\
(55.8-208)\end{array}$ & $\begin{array}{c}114.5 \\
(53-208)\end{array}$ & 0.03 & 0.11 \\
\hline \multicolumn{11}{|l|}{$\begin{array}{l}\text { Underlying condition, } \\
\text { no. }(\%) \text { of } \\
\text { admissions† }\end{array}$} \\
\hline $\begin{array}{l}\text { Any underlying } \\
\text { condition }\end{array}$ & $3(10.7)$ & $44(21.4)$ & $3(7.3)$ & $14(19.2)$ & 27 (29.3) & $23(20.2)$ & $70(20.1)$ & $67(20.9)$ & 0.03 & 0.20 \\
\hline $\begin{array}{l}<36 \text { weeks' } \\
\text { gestation }\end{array}$ & $2(7.1)$ & $42(20.4)$ & $2(4.9)$ & $13(17.8)$ & 27 (29.3) & $21(18.4)$ & $65(18.7)$ & $63(19.7)$ & 0.006 & 0.10 \\
\hline $\begin{array}{l}\text { Cardiac, } \\
\text { respiratory }\end{array}$ & 0 & $7(3.4)$ & $1(2.4)$ & $1(1.4)$ & $5(5.4)$ & $7(6.1)$ & $14(4.0)$ & $14(4.4)$ & 0.50 & 0.65 \\
\hline $\begin{array}{l}\text { Neurologic, } \\
\text { congenital }\end{array}$ & $1(3.6)$ & $2(1.0)$ & 0 & $1(1.4)$ & $1(1.1)$ & 0 & $3(0.9)$ & $2(0.6)$ & 0.40 & 0.22 \\
\hline \multicolumn{11}{|c|}{$\begin{array}{l}\text { Note: } \mathrm{KQR}=\text { Kivalliq Region, } \mathrm{KTR}=\text { Kitikmeot Region, } \mathrm{LRTI}=\text { lower respiratory tract infection, NWT = Northwest Territories, NK = Nunavik, NU = Nunavut, QIR = } \\
\text { Qikiqtaaluk Region. } \\
\text { "For comparison of proportions across regions, } \chi^{2} \text { test was used; for comparison of age, nonparametric test was used; for comparison of admission for lower respiratory } \\
\text { tract infection, Poisson regression was used. } \\
\text { †Some infants had more than } 1 \text { underlying condition. }\end{array}$} \\
\hline
\end{tabular}

\section{Table 2: Outcomes by region}

\begin{tabular}{|c|c|c|c|c|c|c|c|c|c|c|}
\hline \multirow[b]{3}{*}{ Variable } & \multicolumn{8}{|c|}{ Region; subregion } & \multirow{3}{*}{$\begin{array}{c}p \text { value } \\
\text { for NWT } \\
\text { v. all } \\
\text { KTR, } \\
\text { KQR, } \\
\text { QIR, NK }\end{array}$} & \multirow{3}{*}{$\begin{array}{c}p \text { value } \\
\text { for NWT } \\
\text { v. KTR, } \\
\text { KQR, } \\
\text { QIR, NK }\end{array}$} \\
\hline & & \multicolumn{4}{|c|}{ NU } & \multirow[b]{2}{*}{ NK } & \multirow{2}{*}{$\begin{array}{l}\text { All } \\
\text { regions }\end{array}$} & \multirow{2}{*}{$\begin{array}{c}\text { All regions } \\
\text { excluding } \\
\text { NWT }\end{array}$} & & \\
\hline & NWT & Overall & KTR & KQR & QIR & & & & & \\
\hline No. of cases tested for RSV & 26 & 168 & 41 & 59 & 68 & 104 & 298 & 272 & - & - \\
\hline No. of cases in which RSV detected & $\begin{array}{c}14 \\
(53.8)\end{array}$ & $\begin{array}{c}66 \\
(39.3)\end{array}$ & $\begin{array}{c}20 \\
(48.8)\end{array}$ & $\begin{array}{c}28 \\
(47.4)\end{array}$ & $\begin{array}{c}18 \\
(26.5)\end{array}$ & $\begin{array}{c}44 \\
(42.3)\end{array}$ & $\begin{array}{c}124 \\
(41.6)\end{array}$ & $\begin{array}{c}110 \\
(40.4)\end{array}$ & - & - \\
\hline No. of admissions to tertiary hospital & 4 & 49 & 3 & 29 & 17 & 13 & 66 & 62 & - & - \\
\hline No. of admissions for severe LRTI* & 1 & 15 & 2 & 7 & 6 & 5 & 21 & 20 & - & - \\
\hline $\begin{array}{l}\text { Admissions for LRTI among infants } \\
<1 \text { yr per } 1000 \text { live births/yr }\end{array}$ & 39 & 235 & 407 & 243 & 187 & 456 & 189 & 284 & $<0.001$ & $<0.001$ \\
\hline $\begin{array}{l}\text { Admissions for RSV infection among } \\
\text { infants }<1 \text { yr per } 1000 \text { live births/yr }\end{array}$ & 19.7 & 75.3 & 195.1 & 91.2 & 36.7 & 176.0 & 66.9 & 97.6 & $<0.001$ & $<0.001$ \\
\hline $\begin{array}{l}\text { Tertiary admissions per } 1000 \text { live births/ } \\
\text { yr }\end{array}$ & 5.6 & 55.9 & 24.4 & 110.3 & 34.6 & 52.0 & 35.9 & 55.0 & $<0.001$ & $<0.001$ \\
\hline Severe LRTI per 1000 live births/yr & 1.4 & 17.1 & 16.3 & 26.6 & 12.2 & 20.0 & 11.4 & 17.7 & 0.009 & 0.001 \\
\hline
\end{tabular}


the Northwest Territories, compared with 235 in Nunavut and 456 in Nunavik. The rate of admission for respiratory syncytial virus infection per 1000 live births in the Northwest Territories was 19.7, compared to 75.3 in Nunavut and 176 in Nunavik, with the highest of 195.1 in the Kitikmeot Region. The severity of lower respiratory tract infection measured by tertiary admissions and severe lower respiratory tract infections in the Northwest Territories were 5.6 and 1.4 per 1000 live births, respectively, contrasting with Nunavut (55.9 and 17.1, respectively) and Nunavik (52 and 20, respectively).

Viral testing was performed by at least 1 method in 298 $(85.6 \%)$ of the 348 admissions. The combinations of viruses identified are given in Appendix 1 (available at www.cmajopen. ca/content/4/4/E615/suppl/DC1). Table 3 summarizes the organisms identified, alone or as part of a coinfection. Among the 264 cases with positive results, 1 infectious agent was detected in 184 cases (69.7\%), 2 in 67 cases $(25.4 \%), 3$ in 10 cases $(3.8 \%)$, and 4 in 3 cases $(1.1 \%)$. Respiratory syncytial virus was detected in 124 admissions $(41.6 \%$ of admissions with testing for this virus); there were 51 cases of coinfection. Piconaviruses were detected in 111 cases (51 alone, 60 as part of a coinfection). Influenza A (H1N1) was detected in 36 infants (12.1\% of those tested).

Longer length of stay was associated with isolation of more than 1 virus versus 1 virus (OR 2.64, 95\% CI 1.03-6.78) and with the presence of underlying risk factors (OR 4.39, 95\% CI 1.61-11.94). Length of stay decreased by $32.2 \%$ for every 30 -day increase in patient age (OR 0.68, 95\% CI 0.54-0.84). When we assessed the impact of number of viruses on the model, the OR for longer length of stay was 2.7 (95\% CI 1.38-5.30) for each additional virus and 4.73 (95\% CI 1.7113.10) for underlying risk factors; length of stay decreased by

Table 3: Summary of infectious agents identified

\begin{tabular}{|c|c|c|c|}
\hline \multirow[b]{2}{*}{ Infectious agent } & \multicolumn{3}{|c|}{$\begin{array}{c}\text { No. }(\%) \text { of cases } \\
\quad(n=298)\end{array}$} \\
\hline & Alone & Coinfection & Total \\
\hline $\begin{array}{l}\text { Respiratory syncytial } \\
\text { virus }\end{array}$ & $73(24.5)$ & $51(17.1)$ & $124(41.6)$ \\
\hline $\begin{array}{l}\text { Enterovirus/ } \\
\text { rhinovirus }\end{array}$ & $51(17.1)$ & $60(20.1)$ & $111(37.2)$ \\
\hline $\begin{array}{l}\text { Influenza all } \\
\text { subtypes }\end{array}$ & $36(12.1)$ & $12(4.0)$ & $48(16.1)$ \\
\hline Influenza A (H1N1) & $17(5.7)$ & $19(6.4)$ & $36(12.1)$ \\
\hline $\begin{array}{l}\text { Parainfluenza all } \\
\text { subtypes }\end{array}$ & $14(4.7)$ & $13(4.4)$ & $27(9.1)$ \\
\hline $\begin{array}{l}\text { Human } \\
\text { metapneumovirus }\end{array}$ & $11(3.7)$ & $9(3.0)$ & $20(6.7)$ \\
\hline Adenovirus & $4(1.3)$ & $9(3.0)$ & $13(4.4)$ \\
\hline Human coronavirus & $2(0.7)$ & $7(2.3)$ & $9(3.0)$ \\
\hline Bordetella pertussis & $1(0.3)$ & $7(2.3)$ & $8(2.7)$ \\
\hline Bocavirus & $0(0.0)$ & $3(1.0)$ & $3(1.0)$ \\
\hline Cytomegalovirus & $1(0.3)$ & $1(0.3)$ & $2(0.7)$ \\
\hline
\end{tabular}

$34.1 \%$ for every 30 -day increase in patient age (OR 0.66, $95 \%$ CI $0.52-0.83$ ).

Table 4 provides clinical details of the 21 infants who had severe lower respiratory tract infections. Respiratory syncytial virus was detected in 12 of these infants, and 9 (43\%) had more than 1 infection identified. One infant with necrotizing pneumonia attributed to Staphylococcus aureus died en route to a regional centre. This patient required mechanical ventilation for admission with respiratory syncytial virus before the beginning of the study period.

\section{Interpretation}

We found significant regional differences in rates of hospital admission for lower respiratory tract infection: those in the Kitikmeot Region and Nunavik were 10 times higher than that in the Northwest Territories. Furthermore, on average, $5 \%$ of the entire birth cohort of Nunavut and Nunavik required treatment at a tertiary centre, primarily in the intensive care unit, and $1.7 \%-2 \%$ of the birth cohort had severe lower respiratory tract infections requiring life support. Many infants had lengthy hospital stays with mechanical ventilation.

The rates of lower respiratory tract infections in Nunavut and Nunavik are among the highest globally. A case-control study in the Qikiqtaaluk Region identified the following factors as being independently and significantly associated with an increased risk of hospital admission for lower respiratory tract infection: Inuit race, smoking during the pregnancy, residing in communities without a hospital, overcrowding and lack of breastfeeding. ${ }^{11}$ Canadian Inuit, like many other indigenous peoples globally, have major gaps in determinants of health ${ }^{20}$ such as food security ${ }^{21}$ and number of people in the household. ${ }^{22}$

The reason for such a large discrepancy between the Northwest Territories and the other regions is not clear. Contributing factors may include lower unemployment rates and higher per-capita income in the Northwest Territories, ${ }^{23}$ which influence food security and nutrition and, consequently, rates of lower respiratory tract infection. The proportion of Inuit in Nunavut and Nunavik is $80 \%-90 \%$, compared to $11.1 \%$ in the Northwest Territories, ${ }^{24}$ which suggests that an important risk factor may be ethnicity. A 5-year chart review comparing admission rates for lower respiratory tract infection among Inuit infants in Nunavut versus First Nations infants in the Northwest Territories showed a higher incidence among the Inuit despite similar geographic and social conditions. ${ }^{8}$ The authors raised the question of genetic predisposition to severe disease. ${ }^{8}$ Consistent with that hypothesis, a case-control study showed that an Inuit infant with 4 Inuit grandparents had a nearly 4-fold higher risk of hospital admission for lower respiratory tract infections compared to children of mixed race and non-Inuit children. ${ }^{11}$ In a retrospective study of another First Nations group in northern Ontario, McCuskee and colleagues ${ }^{25}$ reported lower rates of respiratory tract infections, 44 per 1000 infant-years, comparable to those in the Northwest Territories but much lower than those in the rest of the Arctic.

Respiratory syncytial virus was the most common virus associated with lower respiratory tract infections in our study, 


\section{OPEN}

Research

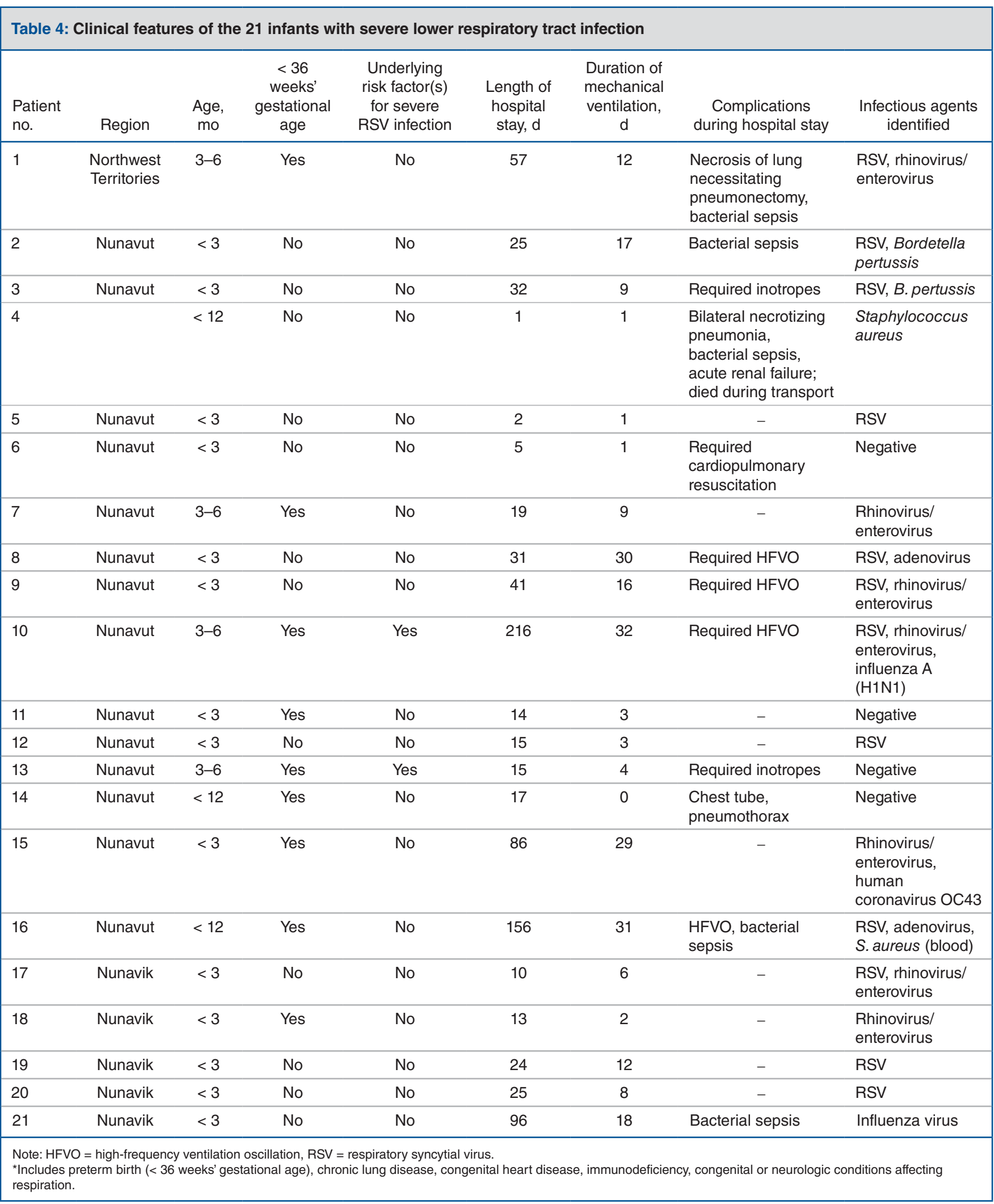

followed by picornaviruses. This distribution is consistent with a recent study of children admitted with communityacquired pneumonia in the United States. ${ }^{26}$ Most of the infants in the current study were born at term, without underlying disease. The annual hospital admission rate for respiratory syncytial virus infection rate in 2002, before the 
introduction of palivizumab, was 166 per 1000 live births in the first year of life and as high as 328 per 1000 live births among infants less than 6 months of age in rural communities in the Qikiqtaaluk Region. This is in contrast to the 5-20 admissions per 1000 live births for US infants. ${ }^{9}$ The annual rates of respiratory syncytial virus infection among infants less than 1 year of age in the Kitikmeot Region and Nunavik in the current study, 195 and 176 per 1000 live births, respectively, are higher than those in sub-Saharan Africa, Latin America and Asia. ${ }^{1}$ Not only are these rates exceedingly high, there are also very large costs associated with these admissions, primarily related to expensive medical evacuation and lengthy stays in the intensive care unit. ${ }^{27}$

Overall, $30 \%$ of infants in whom a virus was detected had coinfection. This is consistent with previous findings in the Qikiqtaaluk Region of viral coinfection rates of $18.2 \%$ by enzyme-linked immunoassay in $1995^{\circ}$ and $21.6 \%$ on initial screening with a direct immunofluorescent panel in $2002 .{ }^{11}$ The significance of viral coinfection remains controversial. Because the polymerase chain reaction method is highly sensitive, it may detect viruses that are not responsible for the illness or from remote infection. In the current study, the length of stay increased with increasing number of viruses detected. Thus, regardless of the biological mechanism, coinfection appeared to be a marker of more severe disease. We hypothesize that a contributor to multiple infections in this population is overcrowding. A previous study showed that overcrowding in the Qikiqtaaluk Region had an independent OR of 2.49 for risk of admission for lower respiratory tract infection. ${ }^{11}$ Canadian Inuit are 10 times more likely than other Canadians to live in overcrowded, substandard housing. ${ }^{22}$ The prevalence of household crowding is higher in Nunavut than in other northern areas (30\% v. $12 \%){ }^{28}$

\section{Limitations}

Retrospective enrolment in the Qikiqtaaluk Region led to incomplete testing in that region. However, with the surveillance and chart review we believe that very few hospital admissions were missed. Not all infants had full viral testing, which underestimates rates of viral detection. Infants admitted to tertiary centres are more likely to have complete testing, which creates a bias toward detection of viruses in sicker infants. Severity of illness was determined only by the length of stay as transfer to tertiary centres may be biased by local expertise and proximity. Although this study was successful in capturing most admissions for lower respiratory tract infections from the Canadian Arctic, milder cases admitted overnight to a local health centre may have been missed. As this study did not capture outpatient visits, the true burden of lower respiratory tract infections is underestimated.

\section{Conclusion}

This study identifies significant geographical variation in lower respiratory tract infections and hospital admission for respiratory syncytial virus infection across the Canadian Arctic. The number of viruses isolated correlated with longer hospital stays. The rates of admission for respiratory syncytial virus infection in the Kitikmeot Region and Nunavik continue to be among the highest globally. Respiratory syncytial virus infection remains one of the most important health issues in these regions and needs to be addressed as a major public health priority, with concerted efforts to reduce the burden of disease.

\section{References}

1. Nair H, Nokes DJ, Gessner BD, et al. Global burden of acute lower respiratory infections due to respiratory syncytial virus in young children: a systematic review and meta-analysis. Lancet 2010;375:1545-55.

2. Koch A, Molbak K, Homoe P, et al. Respiratory tract infections in Greenlandic children: a prospective cohort study. Int $\mathcal{F}$ Circumpolar Health 1998;57 (Suppl 1):252-4.

3. Holman RC, Curns AT, Cheek JE, et al. Infectious disease hospitalizations among American Indian and Alaska native infants. Pediatrics 2003;111:E176-82.

4. Singleton RJ, Petersen KM, Berner JE, et al. Hospitalizations for respiratory syncytial virus infection in Alaska Native children. Pediatr Infect Dis 7 1995;14: 26-30.

5. Banerii A. High rates of hospitalisation for bronchiolitis in Inuit children on Baffin Island. Int 7 Circumpolar Health 2001;60:375-9.

6. Banerji A, Bell A, Mills EL, et al. Lower respiratory tract infections in Inuit infants on Baffin Island. CMA7 2001;164:1847-50.

7. Banerji A, Lanctôt KL, Paes BA, et al. Comparison of the cost of hospitalization for respiratory syncytial virus disease versus palivizumab prophylaxis in Canadian Inuit infants. Pediatr Infect Dis 7 2009;28:702-6.

8. Young M, Kandola K, Mitchell R, et al. Hospital admission rates for lower respiratory tract infections in infants in the Northwest Territories and the Kitikmeot region of Nunavut between 2000 and 2004. Paediatr Child Health 2007;12:563-6.

9. Respiratory syncytial virus infection (RSV): infection and incidence. Atlanta: Centers for Disease Control and Prevention; 2014. Available: www.cdc.gov/ rsv/about/infection.html (accessed 2015 Mar. 19).

10. Shay DK, Holman RC, Newman RD, et al. Bronchiolitis-associated hospitalizations among US children, 1980-1996. 7AMA 1999;282:1440-6.

11. Banerji A, Greenberg D, White LF, et al. Risk factors and viruses associated with hospitalization due to lower respiratory tract infections in Canadian Inuit children: a case-control study. Pediatr Infect Dis 7 2009;28:697-701.

12. Zarychanski R, Stuart TL, Kumar A, et al. Correlates of severe disease in patients with 2009 pandemic influenza (H1N1) virus infection. CMA7 2010; 182:257-64

13. Kumar A, Zarychanski R, Pinto R, et al. Critically ill patients with 2009 influenza $\mathrm{A}(\mathrm{H} 1 \mathrm{~N} 1)$ infection in Canada. FAMA 2009;302:1872-9.

14. Banerji A, Panzov V, Young M, et al. The real-life effectiveness of palivizumab for reducing hospital admissions for respiratory syncytial virus in infants residing in Nunavut. Can Respir 7 2014;21:185-9.

15. Meissner HC, Long SS; American Academy of Pediatrics Committee on Infectious Diseases and Committee on Fetus and Newborn. Revised indications for the use of palivizumab and respiratory syncytial virus immune globulin intravenous for the prevention of respiratory syncytial virus infections. Pediatrics 2003;112:1442-6.

16. Mahony J, Chong S, Merante F, et al. Development of a respiratory virus panel test for detection of twenty human respiratory viruses by use of multiplex PCR and a fluid microbead-based assay. 7 Clin Microbiol 2007;45:2965-70.

17. Mahony J, Chong S, Smieja M, et al. Establishing the epidemiology of respiratory virus infections using molecular technology [abstract]. Proceedings of the 107th Annual Meeting of the American Society for Microbiology, Toronto, May, 2007. Washington: American Society for Microbiology; 2007.

18. Lee BE, Mukhi SN, May-Hadford J, et al. Determination of the relative economic impact of different molecular-based laboratory algorithms for respiratory viral pathogen detection, including pandemic (H1N1), using a secure web based platform. Virol 7 2011;8:277.

19. Aboriginal identity population by age groups, median age and sex, 2006 counts for both sexes, for Canada, provinces and territories - 20\% sample data. Ottawa: Statistics Canada; 2009. Available: www12.statcan.ca/census-recensement/2006/ dp-pd/hlt/97-558/pages/page.cfm?Lang=E\&Geo=PR\&Code=01\&Table $=1 \&$ Data $=$ Count $\&$ Sex $=1 \&$ Age $=1 \&$ StartRec $=1 \&$ Sort $=2 \&$ Display $=$ Page $($ accessed 2012 Nov. 4).

20. Smylie J, Adomako P, eds. Indigenous children's health report: health assessment in action. Toronto: Keenan Research Centre, St. Michael's Hospital; 2009. Available: www.stmichaelshospital.com/crich/wp-content/uploads/ichr report-web.pdf (accessed 2015 Mar. 19).

21. Egeland GM, Pacey A, Cao Z, et al. Food insecurity among Inuit preschoolers: Nunavut Inuit Child Health Survey, 2007-2008. CMA7 2010;182:243-8.

22. 2006 census: Aboriginal peoples in Canada in 2006: Inuit, Métis and First Nations, 2006 census: Inuit. Ottawa: Statistics Canada; 2006. Available: www12. statcan.gc.ca/census-recensement/2006/as-sa/97-558/p7-eng.cfm (accessed 2012 July 11). 
23. Economic indicators, by province and territory (monthly and quarterly) (Northwest Territories). Ottawa: Statistics Canada; 2015. Available: www.statcan.gc.ca/ tables-tableaux/sum-som/101/cst01/indi02m-eng.htm (accessed 2015 Apr. 15).

24. 2006 community profiles. Ottawa: Statistics Canada; 2015. Available: www12. statcan.gc.ca/census-recensement/2006/dp-pd/prof/92-591/index.cfm?Lang=E (accessed 2016 Oct. 11).

25. McCuskee S, Kirlew M, Kelly L, et al. Bronchiolitis and pneumonia requiring hospitalization in young First Nations children in Northern Ontario, Canada. Pediatr Infect Dis 7 2014;33:1023-6.

26. Jain S, Williams DJ, Arnold SR, et al. Community-acquired pneumonia requiring hospitalization among U.S. children. NEngl 7 Med 2015;372:835-45.

27. Banerji A, Panzov V, Robinson J, et al. The cost of lower respiratory tract infections hospital admissions in the Canadian Arctic. Int 7 Circumpolar Health 2013;72 Aug. 5. DOI: 10.3402/ijch.v72i0.21595.

28. Minich K, Saudny H, Lennie C, et al. Inuit housing and homelessness: results from the International Polar Year Inuit Health Survey 2007-2008. Int 7 Circumpolar Health 2011;70:520-31.

Competing interests: Muhammad Mamdani reports personal fees from AstraZeneca, Bristol-Myers Squibb, Eli Lilly and Company, GlaxoSmithKline, Hoffmann-La Roche, Novartis, Novo Nordisk and Pfizer outside the submitted work. Marguerite Dennis reports personal fees and nonfinancial support from St. Michael's Hospital (Research branch) during the conduct of the study and grants, personal fees and nonfinancial support from Abbott Laboratories outside the submitted work.

Affiliations: Li Ka Shing Knowledge Institute (Banerii); Applied Health Research Centre (Panzov, Mamdani, Hall), St. Michael's Hospital, Toronto, Ont.; Dalla Lana School of Public Health (Banerji), University of Toronto, Toronto, Ont.; Department of Pediatrics (Young), Dalhousie University; Department of Emergency Medicine (Young), IWK Health Centre, Halifax, NS; Infectious Diseases (Robinson), Stollery Children's Hospital; Department of Pediatrics (Lee), University of Alberta, Edmonton Clinic Health Academy, Edmonton, Alta.; Division of Respiratory Medicine (Moraes), Department of Pediatrics, Hospital for Sick Chil- dren, Toronto, Ont.; Respirology (Giles), Winnipeg Children's Hospital; Department of Community Health Sciences (Jiang); J.A. Hildes Northern Medical Unit (Bisson), University of Manitoba, Winnipeg, Man.; Pediatrics (Dennis), Sunnybrook Health Sciences Centre, Toronto, Ont.; Pediatrics (Morel), Montreal Children's Hospital, Montréal, Que.; Department of Pediatrics (Hui), Children's Hospital of Eastern Ontario, Ottawa, Ont.; Department of Pediatrics (Paes), McMaster Children's Hospital; Department of Virology Laboratory (Mahony), St. Joseph's Hospital, Hamilton, Ont.

Contributors: Anna Banerji, Val Panzov, Michael Young, Joan Robinson, Bonnita Lee, B. Louise Giles, Danny Bisson, Johanne Morel, Judith Hall, Bosco Paes and Charles Hui contributed to study conception. All of the authors contributed to the study design. Marguerite Dennis and Val Panzov collected the data. Theo Moraes and Depeng Jiang contributed to interpretation of the data. All of the authors contributed to analysing the data and writing and revising the article critically for important intellectual content, approved the final version to be published and agreed to act as guarantors of the work.

Funding: This study was the winner of an investigator-led international call for proposals through Abbott Laboratories. Abbott Laboratories was not involved in the design, implementation, analysis or conclusion of the study.

Acknowledgements: This study is dedicated to the memory of our coinvestigator, Michael Davis. The authors thank Inuit Tapiriit Kanatami, Pauktuutit, Nunavut Tunngavik Inc. and the territorial chief medical officers of health for their input. They also thank Rosane Nisenbaum for biostatistical support and acknowledge the advice and editorial comments from Rosalyn Singleton, Alaska Native Tribal Health Consortium.

Supplemental information: For reviewer comments and the original submission of this manuscript, please see www.cmajopen.ca/content/4/4/ E615/suppl/DC1 